\title{
Mechanism of water-binding and water-retention of food additives nanoparticles based on double oxide of two- and trivalent iron
}

\author{
Iryna Tsykhanovska ${ }^{1}$, Victoria Evlash ${ }^{2}$, Olga Blahyi ${ }^{1}$ \\ 1 - Ukrainian Engineering-Pedagogics Academy, Kharkiv, Ukraine \\ 2 - Kharkiv State University of Nutrition and Trade, Kharkiv, Ukraine
}

\section{Keywords:}

Water

Binding

Retention,

Nanoparticle

Iron oxide

Clusterophilicity

\section{Article history:}

Received

25.05.2019

Received in revised

form 19.11.2019

Accepted

30.06 .2020

\section{Corresponding} author:

Iryna Tsykhanovska

E-mail:

cikhanovskaja@

gmail.com

DOI:

$10.24263 / 2304-$

974X-2020-9-2-4

\section{Abstract}

Introduction. The mechanism of water-binding and water-retention health additives based on double oxide of two- and trivalent iron "Magnetofood" $\left(\mathrm{Fe}_{3} \mathrm{O}_{4}\right)$.

Materials and methods. A model system based on nanoparticles of the "Magnetofood" $\left(\mathrm{Fe}_{3} \mathrm{O}_{4}\right)$ additive is added to water, starch, egg white, fat, linoleic acid, wheaten wheat. water-retaining capacity (WRC) was achieved by energy dispersive $\mathrm{x}$-ray (EDX) and IR-Fourier spectroscopy (FTIR), the Shokh method, the indicator method (IM), the differential thermal analysis (DTA), the coefficient of water absorption $\left(\mathrm{cm}^{3} / \mathrm{g}\right)$ was determined on the Dogadkina device, the swelling properties of powder raw materials, effective viscous flow at the Reotest -2 rotational viscometer.

Results and discussion. The mechanism of interaction of food additive nanoparticles based on double oxide of two- and trivalent iron "Magnetofood" (FAM) by self-organization of nanoparticles of the additive ( $\mathrm{NP} \mathrm{Fe}_{3} \mathrm{O}_{4}$ ) in electrostatic complexes with proteins, polysaccharides and fats such as "clusters", "cavitates", "clathrates". It was found that in food systems that contain proteins, polysaccharides, water, their university is adjusted due to the "clusterophilicity" of FAM and the ability of $\mathrm{NP} \mathrm{Fe}_{3} \mathrm{O}_{4}$ to polarize, electrostatic coordination, the formation of aqua associates.

A shift in the maximum absorption of the $\mathrm{Fe}-\mathrm{O}$ bond was detected in the high-frequency region by $(57 \pm 2) \mathrm{cm}^{-1}$ compared with the experimental sample of pure FAM indicates the chemical interaction of iron cations with FAM molecules of macromolecular compounds (starch, egg white, fat).

The chemical composition is determined of model systems of macromolecular compounds with FAM: for particles of pure FAM - Fe particles 75,5\%; O 24,5\%; for additive particles coated with egg white - Fe 44,7\%; O 26, 9\%; C 21,4\%; N 5,9\%; S 1,1\%; for additive particles coated with starch $-\mathrm{Fe} 41,7 \%$; O 35,7\%; C 22,6\%; for additive particles coated with linoleic acid - Fe 45,6\%; O 34,7\%; C 19,7\%; for additive particles coated with sunflower oil - Fe 39,7\%; O 36,7\%; C 23,67\%.

The ratio established of bound and free moisture in solvated FAM: the amount of bound water: physico-chemical 68,9-69,4\%, physicomechanical 21,5-22,3\% and free 8,8-9,1\%.

Conclusions. For the first time, models of the interaction of NP $\mathrm{Fe}_{3} \mathrm{O}_{4}$ with water, proteins, fats, and carbohydrates have been proposed to substantiate the mechanism of water-retention of food additive nanoparticles based of double oxide of two- and trivalent iron. 


\section{- Food Technology -}

\section{Introduction}

One of the most important functional and technological properties of food raw materials and food systems, which determines the course of technological processes, output, quality and timing of preserving the freshness of finished products, is the water-retaining capacity (WRC), that is, the ability to bind and retain water. The study of the mechanisms of binding and retention of water by food ingredients will allow rational use of new types of food raw materials and predict the behavior of components in food systems during cooking and storage of finished products.

To improve water-retaining capacity of raw materials and food systems, used food additives of different origin: chemical compound (ammonium salt ortofosfornoj acids; meta-, ortho-, poly-, pyrophosphates of sodium, potassium; lactates, citrates, etc) [1]; the special composition of enzymes DSM [2,3]; biologically active substance of vegetable, fruit and herbal additives [4-7]; a variety of polysaccharides: citrus fibre; hydrocolloid vegetable (banana and Apple powder; coconut meal; guar and xanthan gums), Polydextrose, cellulose ethers [5-11]; natural powdery substance on the basis of dairy and egg products [12-15]; functional ingredients derived from industrial by-products (skin, hooves, feathers, offal, seeds, bran, whey, etc.) [16, 17]; supplements of different chemical composition: based on wheat, soybean, chickpea, enzymes, microalgae, and others [18-22]; nanoparticles of metal oxides (especially $\mathrm{ZnO}$ deposited on a film of carboxyme-thylcellulose) [2325]; micro- and nano-sized meat, fish, avian powders [23, 24].

The main disadvantages of known additives are narrow focus and lack of comprehensive action. At the same time, the performance of nano-additives in innovative food products is determined by a wide range of functional and technological properties, due to their high dispersion, shape, structure and physical and chemical parameters.

Modern achievements and experience of domestic and foreign specialists in the field of innovative food technologies [1-25] allow us to apply their results for further research and use of nanomaterials, in particular metal oxides with stable physical and chemical indicators for correcting the functional and technological properties of food raw materials and improving consumer characteristics of food products [24, 25].

Interaction of nanoparticles with biopolymers of food systems (proteins, carbohydrates, lipids) is a complex of complex chemical reactions. An important role is played by the supramolecular organization of nanoparticles and the structure of the organic matrix, which results in the formation of spatial nanostructures that significantly affect the functional and technological properties of raw materials and food systems [26-35].

Therefore, the work on creating new functional and technological properties of food systems using nano-powders food additives of complex action is relevant. It is important to understand the mechanisms of water-binding and water-retention.

Since there is insufficient data on the study and justification of the mechanism of waterpermeation capacity of food additives in the nanometer range, in this paper we present research related to the determination of the nature of interaction of food nanoparticles based on double oxide of two- and trivalent iron "Magnetofood" (FAM) with water, proteins, fats, polysaccharides - the main components of the technological environment. FAM has stable physical and chemical parameters, a wide range of functional and technological properties (structure-forming, stabilizing, water- and fat- retention, sorption, etc.) and promising technological applications [30-42].

The aim of the research is to study the mechanism of water-binding and water-retention by nanoparticles of a food additive based on double oxide of two- and trivalent iron "Magnetofood" (FAM).

To achieve this goal, the following tasks were set:

- To study the mechanism of interaction of high-molecular compounds (starch, egg protein, higher fatty acid, fat) with FAM nanoparticles using IR spectroscopy; 
- $\quad$ To establish the chemical composition of experimental samples of FAM pure and coated with starch, egg white, linoleic acid, sunflower oil using energy-dispersive x-ray spectroscopy;

- To study the water-binding and water-retention of FAM by determining the coefficient of water absorption in various media, the degree of swelling, the water absorption capacity of the food additive;

- Determine the indicator method and differential thermal analysis of the ratio of bound and free moisture in solvated FAM;

- To study the effect of FAM nanoparticles on water-retention, swelling and effective viscosity of model systems of rye-wheat flour and starch.

\section{Materials and methods}

\section{Materials}

Research object: water-retaining capacity of powdered ingredients of food raw materials, in particular nanoparticles of a food additive based on double oxide of two-and trivalent iron "Magnetofood" (FAM).

Research subjects:

- Food additive based on double oxide of two-and trivalent iron "Magnetofud" (FAM) [Patent UA. 126502; TC U 10.8-2023017824-001:2018] - a highly dispersed brown or black powder with a particle size of $70-80 \mathrm{~nm}$. The chemical composition of FAM is double iron oxide $\left(\mathrm{FeO} \cdot \mathrm{Fe}_{2} \mathrm{O}_{3}\right.$ or $\left.\mathrm{Fe}_{3} \mathrm{O}_{4}\right)$, which was obtained by chemical coprecipitation from aqueous solutions of ferrous and trivalent salts in an alkaline medium [36];

- Model system: suspension of FAM in water - obtained by dispersing the calculated amount of FAM in drinking water deaerated and demineralized at a temperature of 18 $20{ }^{\circ} \mathrm{C}$ for $(5-7) \times 60 \quad \mathrm{~s}$, followed by holding for $(10-12) \times 60$ s [33]; "starch+magnetofood", "egg white+magnetofood", "linoleic acid+magnetofood", "sunflower oil+magnetofood", "rye-wheat flour (60:40) (RWF)+magnetofood": suspension of FAM in $1 \%(13 \%)$ starch (flour) solution was obtained by introducing the calculated amount of FAM in $1 \%(13 \%)$ starch (flour) solution) at a temperature of (20-23) ${ }^{\circ} \mathrm{C}$ due to constant mixing $\mathrm{n}=(2,0-2,2) \mathrm{s}^{-1}$ for $(5-7) \times 60 \mathrm{~s}$ [37]. Suspension of FAM in $3 \%$ egg white solution was obtained by introducing the calculated amount of FAM in $3 \%$ egg white solution at a temperature of $(18-20){ }^{\circ} \mathrm{C}$ by constant stirring $\mathrm{n}=(2,0-2,2) \mathrm{s}^{-1}$ for $(3-5) \times 60 \mathrm{~s}$, followed by holding for $(5-7) \times 60 \mathrm{~s}$ [38]. Fat suspensions of FAM were obtained by peptising the calculated amount of FAM into oil (linoleic acid) at a temperature of $(45-50){ }^{\circ} \mathrm{C}$ (rational ratio of components -FAM: fat $(\mathrm{wt} . \%)=50: 50$; that is, $2.5 \mathrm{~g}$ of suspension contains $1.25 \mathrm{~g}$ of FAM) with careful mixing $\left(\mathrm{n}=2.0-2.2 \mathrm{~s}^{-1}\right)$ for $(3-4) \times 60 \mathrm{~s}$, followed by cooling the mixture to a temperature (1820) ${ }^{\circ} \mathrm{C}$ due to constant mixing $\mathrm{n}=(2.0-2.2) \mathrm{s}^{-1}[34,35,39-42]$.

\section{Research methods}

\section{Fourier-infrared spectroscopy (FTIR)}

Vibrational spectra of experimental samples were obtained using the method of IRFourier spectroscopy [50] on a Tensor 37 Fourier spectrometer manufactured by Bruker (Germany), controlled by the OPUS software package with standard calibration capabilities 
in the frequency range (4000-400) $\mathrm{sm}^{-1}$ in the absorption format (IR-Fourier spectra of samples were taken in $\mathrm{KBr}$ tablets) [26, 29, 34].

\section{Energy-dispersive x-ray spectroscopy (EDX)}

To establish the chemical composition of the test samples, a scanning electron microscope JSM-820 (JEOL) with an EDX prefix was used. X-ray spectra were obtained by bombarding experimental samples with electrons using a voltage of $20 \mathrm{kV}$ (corresponding to the lines of characteristic spectra of Iron, Carbon, Sulfur, Nitrogen and Oxygen). The determination of the elemental composition of the experimental samples was performed by analyzing the obtained spectra of characteristic x-ray radiation [26, 28, 34, 35].

\section{Indicator refractometric method}

It consists in determining the difference in dry matter between sugar solutions"indicator" and FAM, solvated in sugar solution [43].

The bound moisture was determined by the formula (1):

$$
X=\frac{B \times\left(b_{2}-b_{1}\right)}{P \times b_{2}},
$$

where $X$ - the amount of bound water, $g$ per $1 \mathrm{~g}$ of dry matter;

$b_{1}$ and $b_{2}-$ the initial and final concentration of sucrose solution, $\%$;

$B$ - the mass of $20 \mathrm{~cm}^{3} 10 \%$ sucrose solution, $\mathrm{g}$;

$P$ - the weight of dry matter, $\mathrm{g}$.

Free moisture was determined by the formula (2):

$$
Y=\frac{\left(C_{0}-C_{1}\right) \times m \times 100}{C_{1} \times g \times W},
$$

where $Y$ - free water content, $\%$ of the total content;

$C_{0}, C_{1}$-initial and final concentrations of sucrose solution, $\%$;

$m$ - mass of the initial sucrose solution, $\mathrm{g}$;

$g$ - weight, g;

$W$ - total water content in $1 \mathrm{~g}$ of the sample, $\mathrm{g}$.

\section{Differential thermal analysis (DTA)}

Thermographic determination was performed on the derivatograph system Q-1500D of the company MOM (Hungary) for the weight of samples $0.5 \mathrm{~g}$ for the following modes of removal of derivatograms: sensitivity of the DTA - 250 galvanometer, DTG - 500 galvanometer, TG -500 galvanometer, the rate of change of the heating temperature -4 ${ }^{\circ} \mathrm{C} / 60 \mathrm{sec}$ [44]. Based on the $T G$ curve, which corresponds to the process of dehydration, the temperature curve $T$ was built according to the degree of change of the mass $\alpha$ to the temperature T. On the $T G$ curve at $5{ }^{\circ} \mathrm{C}$ was found to change the mass of the sample, which corresponds to the mass fraction of moisture at a temperature $T$, and total mass fraction of moisture, determined in $T G$ curve at the end of the process of dehydration. The degree of change in mass a was calculated using the formula (3):

$$
\alpha=\frac{\Delta m_{T}}{m},
$$

where $\alpha$ is the degree of mass change,

$\Delta m_{T}$ is the change in the mass of the sample at temperature $(\mathrm{T}), 10^{-3} \mathrm{~g}$; $m$ is the total mass fraction of moisture contained in the sample, $10^{-3} \mathrm{~g}$. 


\section{Coefficient of water absorption (degree of swelling) of food additive "Magnetofood"}

The degree of swelling $(\mathrm{Q}, \%)$ was determined on the Dogadkina device at two temperatures: $(20 \pm 1){ }^{\circ} \mathrm{C}$ and $(50 \pm 1){ }^{\circ} \mathrm{C}$ in media traditionally used in food technologies [45] according to the formula (4):

$$
Q=\frac{M_{H}}{M_{O}} \times 100=\frac{\rho V}{M_{O}} \times 100,
$$

where $M_{O}$ - weight of the suspension before swelling, g;

$M_{H}$ - weight of the suspension after swelling, $\mathrm{g}$;

$\rho$-density of the absorbed liquid, $\mathrm{g} / \mathrm{cm}^{3}$;

$V$ - volume of the absorbed liquid, $\mathrm{cm}^{3}\left(V=2 \times D h \times K_{n}\right)$;

$h$ - height of the column of the absorbed liquid, $\mathrm{cm}$;

$D$ - diameter of the tube, $\mathrm{cm}$;

$K_{n}$ - coefficient of the device.

\section{Water absorptive capacity (WAC) of food additive "Magnetofood"}

The method is based on bound moisture at $\mathrm{T}=293 \mathrm{~K}$ by various hydromodule of FAM followed by centrifugation and determination of WAC $\left(\alpha_{\mathrm{m}}, \%\right)$ by standard weight method $[46,47]$ according to the formula (5):

$$
\alpha_{m}=\frac{m-m_{o}}{m_{o}}
$$

where $m_{o}$ and $m$ are the mass of the FAM hitch before and after solvation.

\section{The swelling properties of powder raw materials}

It was determined by infusing $1 \%$ of the water suspension of the experimental sample during the day. Swell $\left(\mathrm{N}_{\mathrm{b}}, \mathrm{cm}^{3} / \mathrm{g}\right)$ was estimated as the maximum amount of water that an object can absorb and hold until dynamic equilibrium occurs, related to the weight of the suspension $[12,42]$.

\section{Water retaining capacity (WRC) of powder raw materials}

WRC (\%) was determined by the Schoch method as the amount of water that was adsorbed and retained by the raw component during the process of infusing and centrifuging the water suspension $[12,48,49]$.

\section{Effective viscosity}

It was determined on a rotary viscometer "Reotest- 2 " in $13 \%$ aqueous suspensions of model systems of starch and flour. The choice of concentration is determined by obtaining solutions with the optimal viscosity for the study on this device. The viscosity of the samples was measured for 30 minutes every $10 \times 60 \mathrm{~s}$ at temperatures of $(23 \pm 2){ }^{\circ} \mathrm{C}$ and $(40 \pm 2){ }^{\circ} \mathrm{C}$ $[12,48,49]$. 


\section{Results and discussion}

\section{Scientific justification of the interaction of FAM with the main components of food systems - proteins, fats, polysaccharides, water}

The chemical activity of "Magnetofood" nanoparticles (NPM) is determined mainly by electrostatic - dipole-dipole (vandervaals) and ion-dipole interactions. Donor-acceptor (coordination) interactions, such as hydrogen bonds, are also involved in the adsorption of proteins, fats, carbohydrates, and water on the surface of the NPM [26, 28-35].

Figure 1 shows the schemes of NPM solvation, which explains the regularities of the formation of the properties of food systems, in particular the bound water capacity. On the surface of the NPM are variously polarized areas $\left({ }^{+\delta} \mathrm{Fe}\right)$ and $\left({ }^{-\delta} \mathrm{O}\right)$. The $\mathrm{Fe}^{2+}$ and $\mathrm{Fe}^{3+} \mathrm{NPM}$ cations are structure-forming [26, 28, 30]. High tension electric field created by cations of iron magnetic nanoparticles additives, enhances the polarization of the molecules that are next and this contributes to a further ordering of the dipoles (e.g., peptide bonds, $\mathrm{HO}^{-}$-groups, $\mathrm{COO}^{-}$-groups, $\mathrm{H}_{2} \mathrm{O}$ and others) outside the particle surface and chemisorption [26, 28-31].

In a neutral environment ( $\mathrm{pH}=6,8-7,0)$, polarized NPM are formed (Figure 1, a), which then pass into solvated particles and solvated aquacomplexes [30]. In an acidic environment $(\mathrm{pH}<6,8)$ (Figure 1, b), protonated, then solvated-protonovani NPM, which then form solvated aquaasociati [30]. In an alkaline environment ( $\mathrm{pH}>7,0)$ (Figure 1, c), hydroxylating NPM are first formed, then solvated-hydroxylating NPM arise, which then form solvatocomplexes [30].

For a more detailed explanation of the mechanism of interaction of proteins, polysaccharides, and fats with NPM, consider the electrostatic coordination interactions that occur between NPM and the ionogenic groups of these compounds. As a result, electrostatic complexes are formed: "clathrates" (Figure 2) and "cavitati" (Figure 3) [30-32].

In an internal molecular complex - "clathrate" (Figure 2, a) of the "complex-cell" type (Figure2, b), the donor is a Nitrogen atom of the heterocyclic systems Histidine (His) and Tryptophan (Trp), which has a free electron pair on the outer shell. NPM ferum cations ( $\mathrm{Fe}^{2+}$, $\mathrm{Fe}^{3+}$ ), which have vacant 3d-orbitals, act as a complex-forming acceptor. As a result, three intramolecular coordination ligaments are formed that strengthen the electrostatic complex [30].

Complex associates of polyheterocyclic ligands of protein molecules with NPM, combining fragments of two polypeptide chains of histidine and tryptophan with iron cations $\left(\mathrm{Fe}^{2+}, \mathrm{Fe}^{3+}\right)$ due to intermolecular complexation, are the mizmolecular complex "cavitat" "NPM+protein".

In addition to the fact that the iron cations $\left(\mathrm{Fe}^{2+}, \mathrm{Fe}^{3+}\right)$ of the NPM are coordinated in a linear ligand (Figure 3, a), they also firmly hold a similar ligand located perpendicular (Figure 3 , b). Such a complex structure is strong due to the multiplicity of formed coordination links [30-32].

Under the influence of "Magnetofood" nanoparticles $\left(\mathrm{NPFe}_{3} \mathrm{O}_{4}\right)$ high-molecular compounds (proteins, polysaccharides, higher fatty acids, fats) undergo structural changes, forming fairly stable structures with $\mathrm{NPFe}_{3} \mathrm{O}_{4}$. Figure 4 shows the process of selforganization of $\mathrm{NPFe}_{3} \mathrm{O}_{4}$ into electrostatic complexes with proteins, polysaccharides and fats. The $\mathrm{NPFe}_{3} \mathrm{O}_{4}$ complex with gliadin (Figure 4, a) is stabilized by coordination (donoracceptor) bonds of Fe atoms with Oxygen and Nitrogen atoms of Glutamine and Tryptophan residues, as well as by electrostatic hydrophobic interactions of aliphatic side chains of leucine residues and $\pi$ - $\pi$-stacking interactions of aromatic fragments of tryptophan residues. 

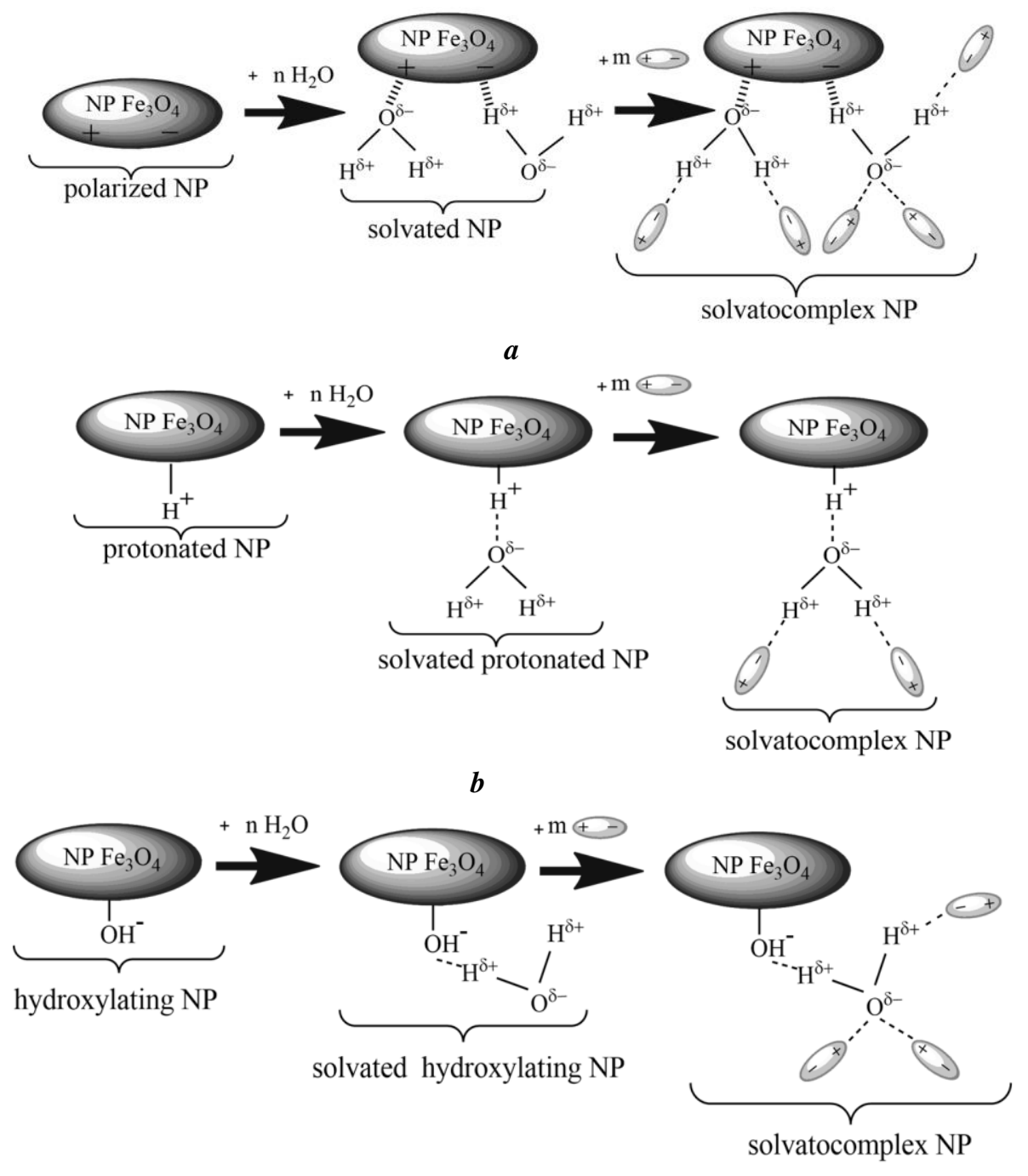

- - covalent bond; $\quad$ "m! - dipole-dipole (electrostatic) interaction.

-..- hydrogen bond; $\leftrightarrow-$ dipole $\mathrm{H}_{2} \mathrm{O}$.

Figure 1. Mechanisms of FAM solvation at different $\mathrm{pH}$ levels in aquatic environments: a - neutral (pH 7.0); b - acidic (pH<7, 0); c - alkaline (pH> 7, 0) 


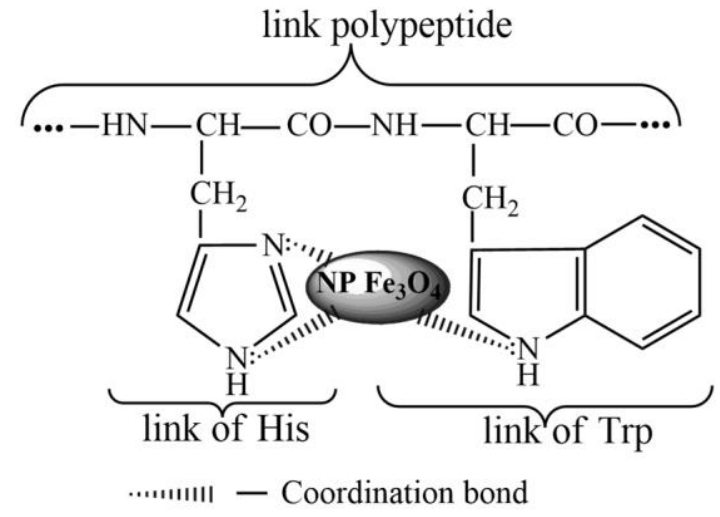

a

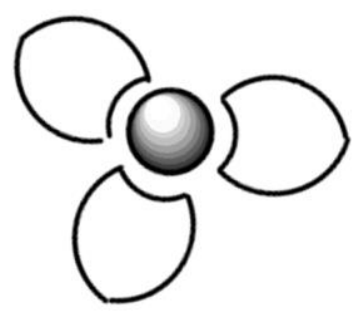

b

Figure 2. Intramolecular complex - "clathrate" type "complex-cell", formed by NPM and a link in the Gliadin polypeptide chain:

$a$ - "clathrate" - "NPM+protein"; $b$ - "complex-cell" - "NPM+protein"

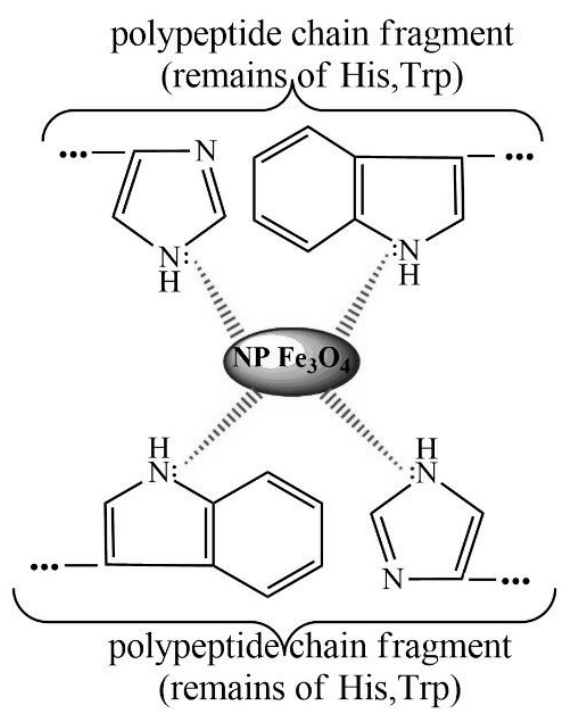

…แ!III - coordination bond

$a$

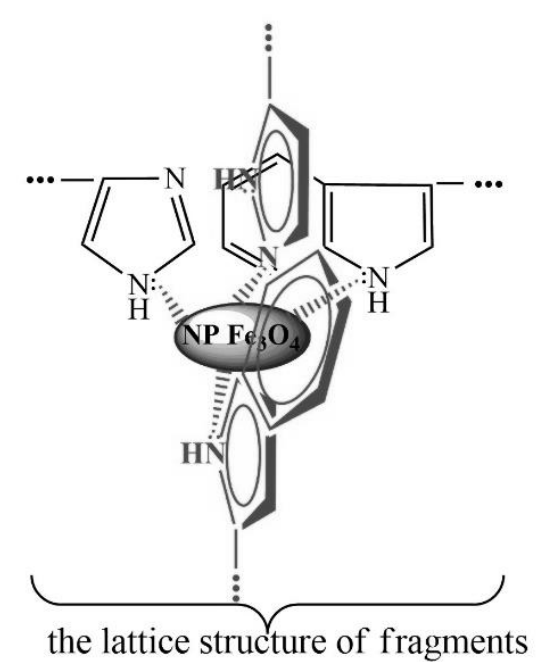

of the polypeptide chain and the complexing agent of the $\mathrm{NP} \mathrm{Fe}_{3} \mathrm{O}_{4}$

b

Figure 3. Intermolecular complex of NPM with links of two polypeptide chains: $a$ - "cavitate" - "NPM+protein"; $b$ - spatial structure "cavitate" - "NPM+protein" 
the link of the polypeptide chain of Gliadin

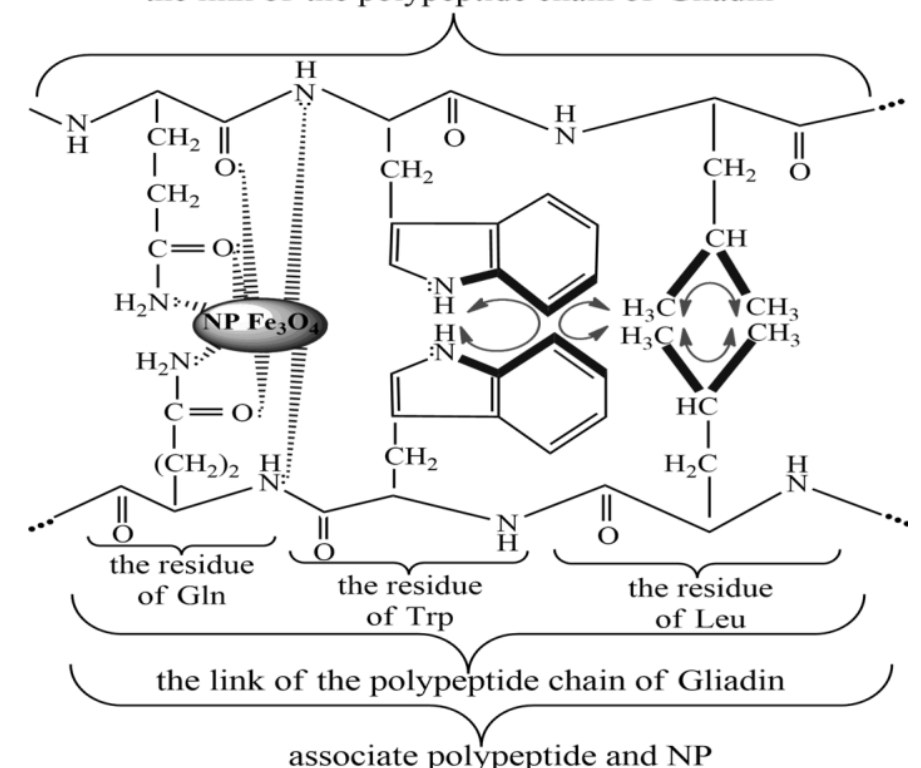

$a$

fragment of a Starch molecule

( link of the polymeric chain of Amylopectin or Amylose)

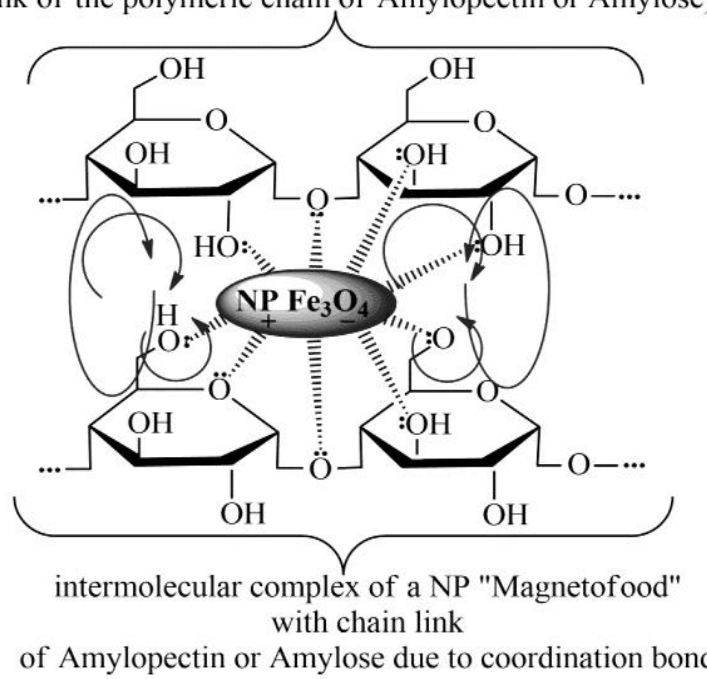

$$
\begin{aligned}
& (\downarrow-\pi-\pi \text { stacking interaction; } \\
& \text { III... - coordination bond. }
\end{aligned}
$$

- electrostatic hydrophobic interaction of "cluster type"

b

Figure 4. Electrostatic complexes of $\mathrm{NPFe}_{3} \mathrm{O}_{4}$ with:

$a$ - protein (gliadin); $b$ - polysaccharide (amylopectin); $c$ - fat (triglyceride) 


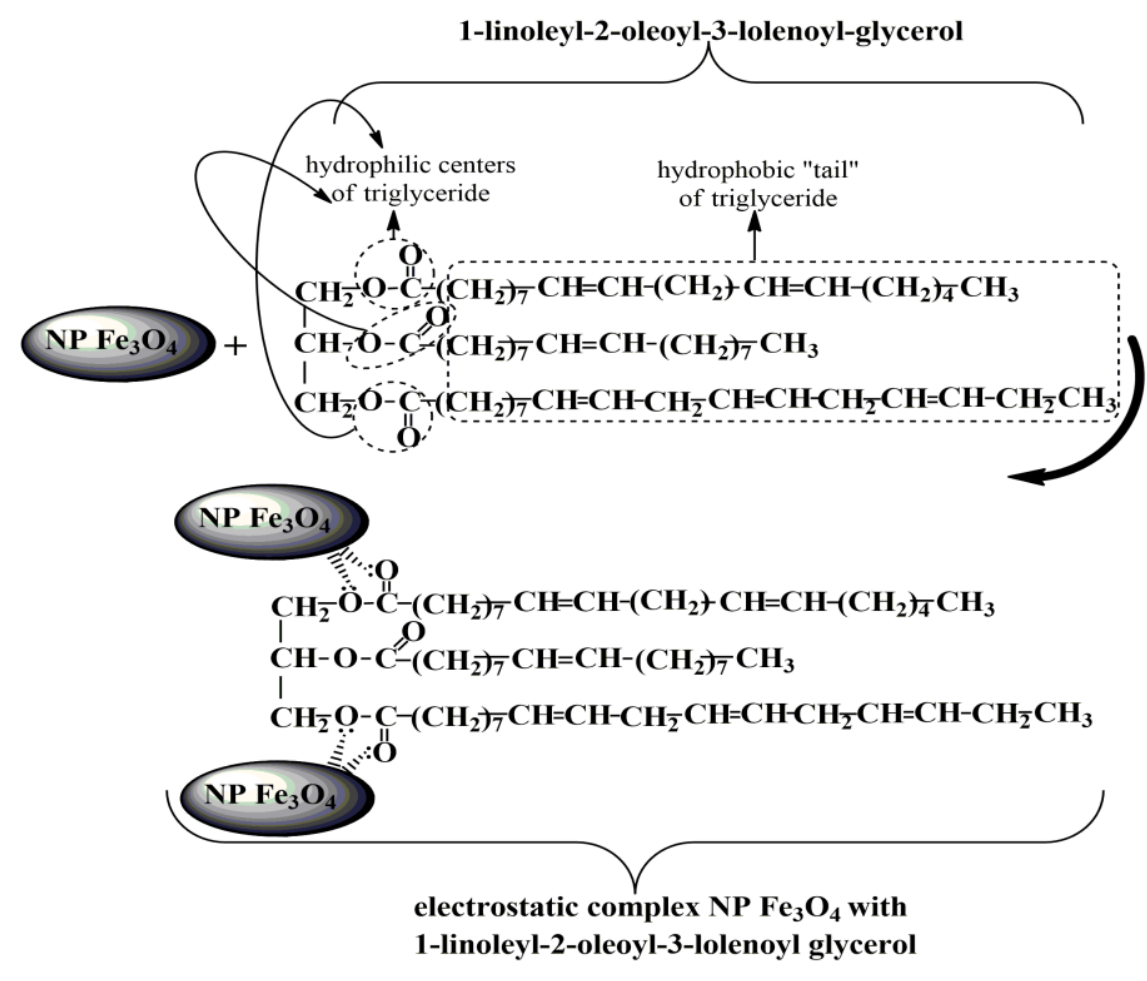

$c$

Figure 4 (Continue). Electrostatic complexes of $\mathrm{NPFe}_{3} \mathrm{O}_{4}$ with: $a$ - protein (gliadin); $b$ - polysaccharide (amylopectin); $c$ - fat (triglyceride)

All this causes a more branched structure and intertwining of protein macromolecules. As a result, there are formations such as "clusters", "clathrates", "cavitates" and "loops" [30$32,34,35]$.

Intermolecular complexes of $\mathrm{NPFe}_{3} \mathrm{O}_{4}$ with links of two main chains of amylopectin (Figure 4, b) are formed due to coordination bonds of Fe atoms with Oxygens (etheric, pyranose and hydroxyl) of D-glucopyranose residues, amplifying the $\pi-\pi$ stacking interaction of pyranose cycles in the "plane-to-plane" type. In the amylopectin molecule, the $\pi-\pi$ stacking interaction is due to electrostatic forces: hydrophobic and dispersive london forces between the glucopyranose residues. All this contributes, first, to an increase in the degree of branching of the main chain of the polysaccharide, in particular amylopectin, and second, to the appearance of "cluster" - type formations [30, 32].

Under the influence of $\mathrm{NPFe}_{3} \mathrm{O}_{4}$, fats undergo structural changes, forming supramolecular associations from $\mathrm{NPFe}_{3} \mathrm{O}_{4}$ - electrostatic complexes (Figure 4, c) due to the coordination bonds of $\mathrm{Fe}$ atoms with Oxygen atoms of the natural group of triglycerides, which causes their chemosorption on the reactively active surface of polar $\mathrm{NPFe}_{3} \mathrm{O}_{4}[34,35]$. Figure 5 shows the bound water of $\mathrm{NPFe}_{3} \mathrm{O}_{4}$ in food systems containing proteins and polysaccharides. 
fragment of polypeptide hydrated chains of Gliadin

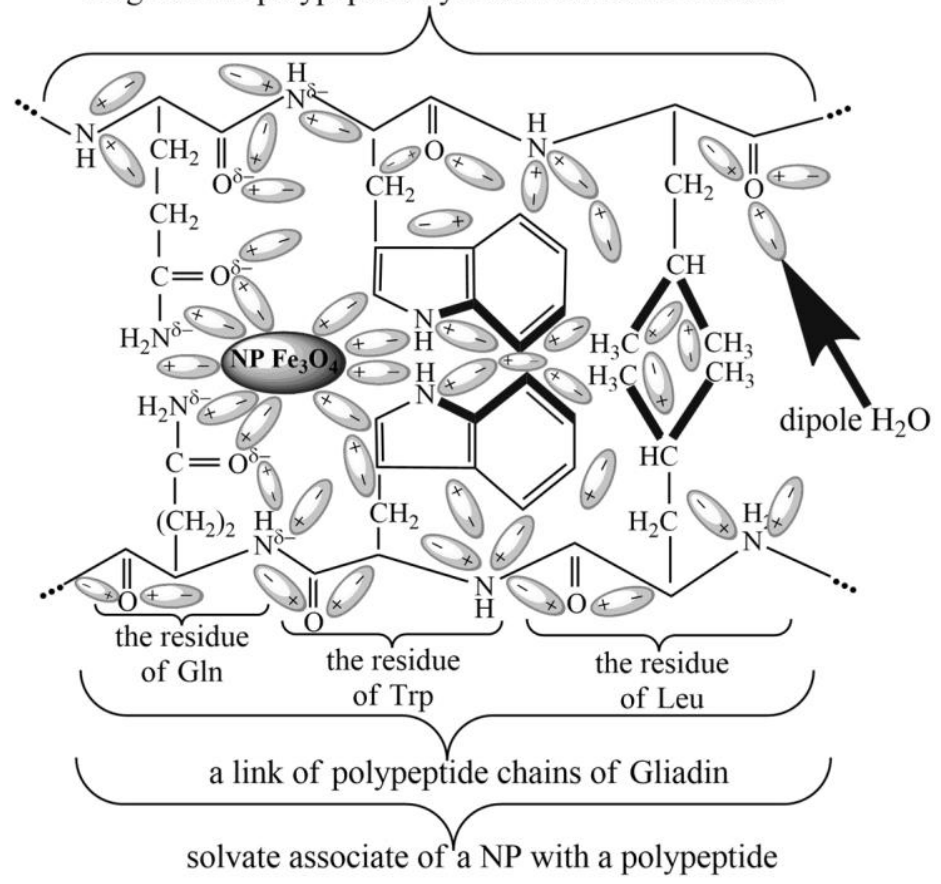

$a$

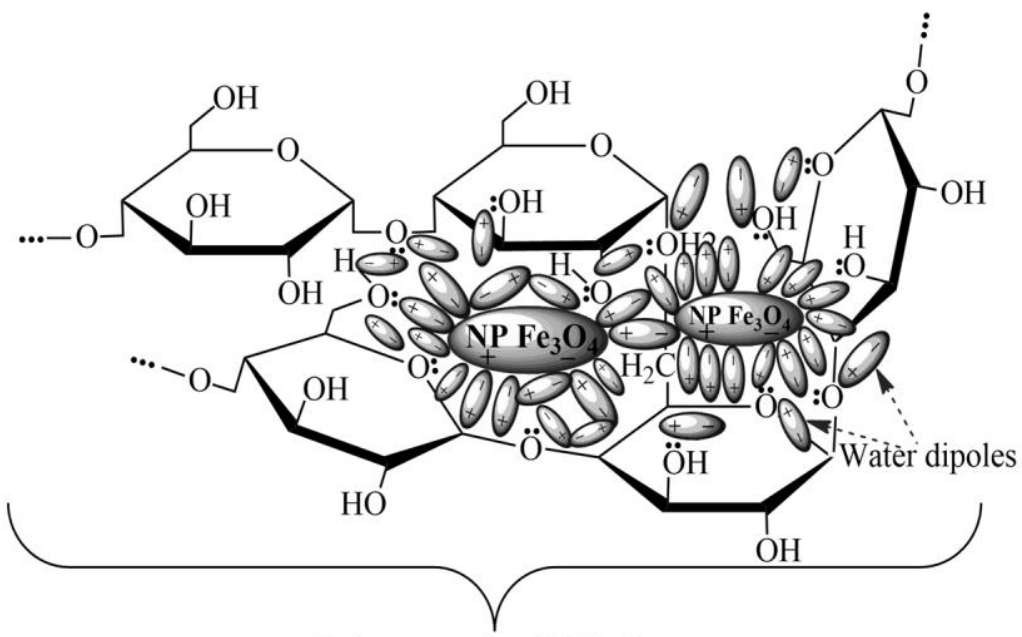

Solvatocomplex NP $\mathrm{Fe}_{3} \mathrm{O}_{4}$

in the "cluster" chain link Amylopectin

$b$

Figure 5. Distribution of water dipoles in "clusters" of links of solvated polymer chains structured by $\mathrm{NPFe}_{3} \mathrm{O}_{4}$ : $a$ - gliadin; $b$ - amylopectin; $c$ - cellulose 


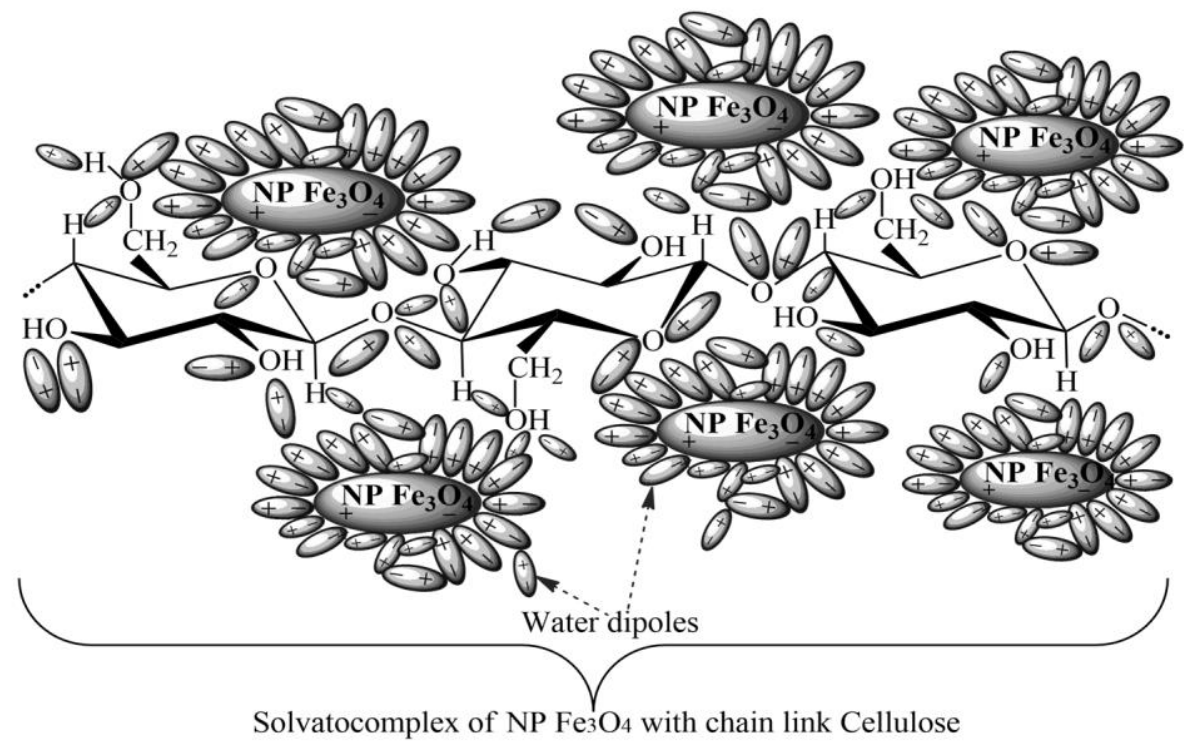

$c$

Figure 5. (Continue). Distribution of water dipoles in "clusters" of links of solvated polymer chains structured by $\mathrm{NPFe}_{3} \mathrm{O}_{4}$ : $a$ - gliadin; $b$ - amylopectin; $c$ - cellulose

Water accumulation is observed around the polar $\mathrm{NPFe}_{3} \mathrm{O}_{4}$ and in "clusters" and "loops" between two Gliadin chains (Figure 5, a), where both intermicellar and intramicellar water can be retained (due to hydrogen, dipole-ion and dipole-dipole bonds with $\mathrm{NPFe}_{3} \mathrm{O}_{4}$ and hydrophilic groups of amino acid residues) [30, 32]. $\mathrm{H}_{2} \mathrm{O}$ dipoles also form hydrogen bonds without breaking the strength. Side branches that appear in the protein macrostructure contribute to the extension of the main chains, without breaking the "cross-linking". This facilitates the interaction of protein macromolecules with $\mathrm{H}_{2} \mathrm{O}$ dipoles and improves the hydration of protein fragments. The result is an increase the WRC of food systems and finished products.

When FAM is introduced into food products (in particular, gel-like type), polysaccharide molecules are exposed to polar $\mathrm{NPFe}_{3} \mathrm{O}_{4}$ (Figure 5, b). That is, when polysaccharides are hydrated in the presence of $\mathrm{NPFe}_{3} \mathrm{O}_{4}$, a system of hydrogen, hydrophobic, electrostatic, and coordination bonds is formed, which contributes to the stability of the carbohydrate structure $[31,32]$. Water molecules, forming hydrogen bonds, penetrate deeper polysaccharides (in particular starch) in the least organized parts of the chain macromolecules of carbohydrate and form of education " $\mathrm{NPFe}_{3} \mathrm{O}_{4}+$ polysaccharide $+\mathrm{H}_{2} \mathrm{O}$ " on type "cluster" (Figure 5, b). $\mathrm{NPFe}_{3} \mathrm{O}_{4}$ form aquacomplex, and in "clusters" occur solvatatsii. This pushes the polymer chains apart and improves water penetration into the starch. This water absorption weakens the micromolecular bonds in dense layers and promotes the penetration of moisture into the most crystalline layers. This process goes through the gelation stage, when the starch grains swell and increase in volume. As a result, the WRC of the carbohydrate-containing system increases. 
Due to the open (linear unbranched) structure of cellulose (Figure 5, c), the availability of hydrophilicity centers $\left(\mathrm{NPFe}_{3} \mathrm{O}_{4}, \mathrm{OH}^{-}\right.$-groups, etc.), the high reactivity and complexopening ability of polar $\mathrm{NPFe}_{3} \mathrm{O}_{4}$ increases the energy potential of hydrophilic components of cellulose and color: adsorption of $\mathrm{H}_{2} \mathrm{O}$ dipoles in microcapillars (which are built in a threedimensional mesh structure); penetration of $\mathrm{H}_{2} \mathrm{O}$ dipoles inside the cellulose (due to expansion of polymer chains and weakening of micro-macromolecular bonds in dense layers). As a result, solvatoassociates are formed and the water-retaining capacity of the structural polysaccharide (cellulose) increases [31, 32].

Experimental confirmation of interaction of a food additive based on double oxide of two- and trivalent iron "Magnetofood" with proteins, fats, polysaccharides, water

Fourier-infrared spectroscopy. The results of Fourier-IR spectroscopic studies of model systems of egg protein, starch, linoleic acid and sunflower oil with FAM are shown in table 1 and table 2 .

The intensive wide band with the maximum absorption $(3341 \pm 4) \mathrm{cm}^{-1}$ is shifted in the complex asociati to the low-frequency region in comparison with the frequency of free $\mathrm{OH}^{-}$ -groups and Amide A $(\mathrm{N}-\mathrm{H})(3406 \pm 4) \mathrm{cm}^{-1}$ (Table 1). This indicates the participation of hydroxyl Oxygens and amide Nitrogens in the formation of coordination bonds with Fe atoms of FAM [26, 27].

Comparison of wave numbers of individual peaks in the IR-spectra

Table 1 of the complex associate "egg white+magnetofood" and the starting substances

(egg white, food additive "Magnetofood" - FAM)

\begin{tabular}{|c|c|c|c|c|}
\hline \multirow{2}{*}{$\begin{array}{c}\text { Communication } \\
\text { fluctuations }\end{array}$} & \multicolumn{3}{|c|}{ Position of maxima (wave numbers), $\mathrm{cm}^{-1}$} & \multirow{2}{*}{$\begin{array}{c}\text { Offset, } \\
\text { см}^{-1}\end{array}$} \\
\hline & Egg white & FAM & «egg white+magnetofood» & \\
\hline $\begin{array}{l}v(\mathrm{O}-\mathrm{H}), \\
v(\mathrm{~N}-\mathrm{H}) \text {-Amide } \mathrm{A}\end{array}$ & $3406 \pm 5$ & - & $3341 \pm 5$ & -65 \\
\hline $\mathrm{V}_{\mathrm{as}}(\mathrm{C}-\mathrm{H})$ & $2927 \pm 4$ & - & $2927 \pm 4$ & 0 \\
\hline$v_{\mathrm{s}}(\mathrm{C}-\mathrm{H})$ & - & - & $2360 \pm 4 ; 2342 \pm 3$ & - \\
\hline$v(\mathrm{C}=\mathrm{O})-$ Amide $\mathrm{I}$ & $1653 \pm 3$ & - & $1642 \pm 3$ & -11 \\
\hline$\delta_{\text {pl. }}(\mathrm{N}-\mathrm{H})-$ Amide II & $1539 \pm 3$ & - & $1527 \pm 3$ & -12 \\
\hline$\delta_{\mathrm{pl} .}(\mathrm{C}-\mathrm{H})$ & $1451 \pm 3$ & - & $1442 \pm 3$ & -9 \\
\hline$\delta_{\mathrm{pl} .}(\mathrm{C}-\mathrm{C})$ & $1239 \pm 2$ & - & $1239 \pm 2$ & - \\
\hline$\delta_{\text {ext.pl. }}(\mathrm{C}-\mathrm{C})$ & - & - & $1155 \pm 2$ & - \\
\hline$\delta_{\text {ext.pl. }}(\mathrm{C}-\mathrm{C})$ & $1079 \pm 2$ & - & $1027 \pm 2$ & -52 \\
\hline$v(\mathrm{Fe}-\mathrm{O})$ & - & $532 \pm 2$ & $588 \pm 2$ & +56 \\
\hline
\end{tabular}

There are also intense bands with maxima at $(2360 \pm 4) \mathrm{cm}^{-1}$ and $(2342 \pm 3) \mathrm{cm}^{-1}$, which are absent in the egg protein spectrum. These peaks can be attributed to the symmetric valence $\left(v_{\mathrm{s}}\right)$ oscillations of the $\mathrm{C}-\mathrm{H}$ bond, which is confirmed by the electrostatic hydrophobic interactions of aliphatic side chains of amino acid residues in "clathrates" and "cavitates", which occur under the action of $\mathrm{NPFe}_{3} \mathrm{O}_{4}$ [27]. During the adsorption of egg white on the surface of the $\mathrm{NPFe}_{3} \mathrm{O}_{4}$, the absorption bands of valence vibrations of Amide I $\mathrm{v}(\mathrm{C}=\mathrm{O})$ and plane deformation vibrations of Amide II $\delta_{\mathrm{pl}}(\mathrm{N}-\mathrm{H})$ are shifted to a lower 
frequency in the region: $v(\mathrm{C}=\mathrm{O})=(1642 \pm 3) \mathrm{cm}^{-1} ; \delta_{\mathrm{pl}}(\mathrm{N}-\mathrm{H})=(1527 \pm 3) \mathrm{cm}^{-1}$, respectively $[27$, 34].

The absorption bands of plane and out-of-plane deformation vibrations $\delta_{\mathrm{pl}}(\mathrm{C}-\mathrm{H})$ and $\delta_{\text {ext.pl. }}(\mathrm{C}-\mathrm{C})$ are shifted to a lower frequency - in the region: $\delta_{\text {pl. }}(\mathrm{C}-\mathrm{H})=(1442 \pm 3) \mathrm{cm}^{-1}$ and $\delta_{\text {ext.pl. }}(\mathrm{C}-\mathrm{C})=(1027 \pm 2) \mathrm{cm}^{-1}$ respectively, a new absorption band of plane deformation vibrations $\delta_{\mathrm{pl}}(\mathrm{C}-\mathrm{C})=(1155 \pm 2) \mathrm{cm}^{-1}$ is also observed. This is confirmed by the electrostatic hydrophobic interactions of aliphatic and cyclic amino acid residues in complex associate $[27,34]$.

In the spectrum of pure FAM (Table 1), there is an absorption line of the $\mathrm{Fe}-\mathrm{O}$ bond with a maximum value of $\sim 532 \mathrm{~cm}^{-1}$, which is in good agreement with the data from literature sources of $\sim 530 \mathrm{~cm}^{-1}[26,28,35]$. The shift of the maximum of the corresponding absorption band of the $\mathrm{Fe}-\mathrm{O}$ bond valence vibrations in the "egg protein+magnetofood" complex to the region of $\sim 588 \mathrm{~cm}^{-1}$ is due to the influence of surface egg protein molecules, their interference in the near-surface layer of $\mathrm{Fe}_{3} \mathrm{O}_{4}$ nanoparticles and chemical interaction with ferum cations. Thus, the research results confirm the formation of a complex between egg protein and $\mathrm{NPFe}_{3} \mathrm{O}_{4}$.

Comparison of IR-spectra (Table 2) shows that the wave numbers of peaks differ in the spectra of the initial substances (starch, FAM) and the "starch+magnetofood" complex, indicating the chemical interaction in the carbohydrate-magnetofood model system. In the spectrum of the "starch+magnetofood" complex, there is a shift of the intense band of free $\mathrm{OH}^{-}$-groups $(3443 \pm 5) \mathrm{cm}^{-1}$ to the low-frequency region $-(3415 \pm 5) \mathrm{cm}^{-1}$, which indicates the participation of hydroxyls in the topic of hydrogen bonds and electrostatic coordination interactions with Fe atoms of FAM [26, 27].

Table 2

Comparison of wave numbers of individual peaks in the IR-spectra of the complex associate "starch+magnetofood" and initial substances (starch, FAM)

\begin{tabular}{|c|c|c|c|c|}
\hline \multirow{2}{*}{$\begin{array}{l}\text { Communication } \\
\text { fluctuations }\end{array}$} & \multicolumn{3}{|c|}{ Position of maxima (wave numbers), $\mathrm{cm}^{-1}$} & \multirow[t]{2}{*}{ Offset, $\mathrm{cm}^{-1}$} \\
\hline & Starch & FAM & «starch+magnetofood» & \\
\hline$v(\mathrm{O}-\mathrm{H})$ & $3443 \pm 5$ & - & $3415 \pm 5$ & -28 \\
\hline$v_{\text {as }}(\mathrm{C}-\mathrm{H})$ & $2927 \pm 4$ & - & $2917 \pm 4$ & -10 \\
\hline$v_{\mathrm{s}}(\mathrm{C}-\mathrm{H})$ & - & - & $2360 \pm 4 ; 2342 \pm 3$ & - \\
\hline$v(\mathrm{C}-\mathrm{O}-\mathrm{C})$ & $1653 \pm 3$ & - & $1640 \pm 3$ & -13 \\
\hline$\delta_{\mathrm{pl} .}(\mathrm{C}-\mathrm{O}-\mathrm{C})$ & $1457 \pm 3$ & - & $1441 \pm 3$ & -16 \\
\hline$\delta_{\mathrm{pl} .}(\mathrm{C}-\mathrm{C})$ & $1162 \pm 2$ & - & $1152 \pm 2$ & -10 \\
\hline$\delta_{\text {пл. }}(\mathrm{C}-\mathrm{C})$ & - & - & $1081 \pm 2 ; 1021 \pm 2$ & - \\
\hline$\delta_{\text {ext.pl. }}(\mathrm{C}-\mathrm{C})$ & $982 \pm 2$ & & $922 \pm 2$ & -60 \\
\hline$\delta_{\text {ext.pl. }}(\mathrm{C}-\mathrm{C})$ & $857 \pm 2$ & & $847 \pm 2$ & -10 \\
\hline$\delta_{\text {ext.pl. }}(\mathrm{C}-\mathrm{C})$ & $763 \pm 2$ & & $753 \pm 2$ & -10 \\
\hline$v(\mathrm{Fe}-\mathrm{O})$ & - & $532 \pm 2$ & $589 \pm 2$ & +57 \\
\hline
\end{tabular}


Displacement of the peak of valence $v(\mathrm{C}-\mathrm{O}-\mathrm{C})$ by $(13 \pm 3) \mathrm{cm}^{-1}$ and plane deformation vibrations DPL. ( $-\mathrm{O}-\mathrm{C})$ at $(16 \pm 3) \mathrm{cm}^{-1}$ in the low-frequency region in comparison with the experimental starch sample indicates the presence of coulomb and coordination interactions between Fe atoms of FAM and Oxygens (ether, pyranose and hydroxyl) of D-glucopyranose residues [27].

The appearance of new absorption bands in the region (700-1200) $\mathrm{cm}^{-1}$, which characterize the fluctuations of the carbon skeleton, and the shift to the lower frequency region of some characteristic absorption bands $(\mathrm{C}-\mathrm{C})$ bonds indicates the presence of hydrophobic and dispersive london interactions between the residues of glucopiranose [26, 27]. The shift of the maximum absorption of the $\mathrm{Fe}-\mathrm{O}$ bond to the high-frequency region $(57 \pm 2) \mathrm{cm}^{-1}$ in comparison with the experimental sample of pure FAM indicates the chemical interaction of FAM ferum cations with starch molecules. All this confirms the presence of chemical interaction in the complex asociati "starch+magnetofood" [27, 34].

The study of chemosorption of linoleic acid and 1-linoleyl-2-oleoyl-3linolenoylglycerol on the surface of FAM nanoparticles is given in previous studies $[34,35$, 42], which indicates the chemical interaction of higher fatty acid and fat with $\mathrm{Fe}_{3} \mathrm{O}_{4}$ nanoparticles.

\section{Energy-dispersive spectroscopy (EDX)}

The chemical composition of model systems was determined using EDX-spectra: "magnetofood- $\mathrm{Fe}_{3} \mathrm{O}_{4}$ " (sample 1), "starch+magnetofood" (sample 2), "egg protein+magnetofood" (sample 3), "linoleic acid+magnetofood" (sample 4), "sunflower oil+magnetofood" (sample 5) (Table 3).

Table 3

Chemical composition of experimental samples of compositions "protein (or fat or polysaccharide)+magnetofood" based on the results of EDX-spectra

\begin{tabular}{|c|c|c|c|c|c|c|}
\hline \multirow{3}{*}{ Samples } & \multicolumn{6}{|c|}{ Elemental composition } \\
\hline & \multicolumn{2}{|c|}{$\mathbf{F e}$} & \multicolumn{2}{|c|}{$\mathbf{O}$} & \multicolumn{2}{|c|}{$\mathbf{C}$} \\
\hline & Mass\% & Atomic\% & Mass\% & Atomic\% & Mass \% & Atomic\% \\
\hline 1 & $75,5 \pm 3,7$ & $42,9 \pm 2,1$ & $24,5 \pm 1,2$ & $57,1 \pm 2,8$ & - & - \\
\hline 2 & $41,7 \pm 2,1$ & $36,7 \pm 1,8$ & $35,7 \pm 1,6$ & $27,4 \pm 1,4$ & $22,6 \pm 1,1$ & $32,6 \pm 1,6$ \\
\hline $3 *$ & $44,7 \pm 2,2$ & $37,0 \pm 1,7$ & $26,9 \pm 1,3$ & $22,8 \pm 1,1$ & $21,4 \pm 1,0$ & $31,2 \pm 1,5$ \\
\hline 4 & $45,6 \pm 2,3$ & $37,5 \pm 1,7$ & $34,7 \pm 1,5$ & $26,6 \pm 1,3$ & $19,7 \pm 0,9$ & $30,9 \pm 1,4$ \\
\hline 5 & $39,7 \pm 1,9$ & $35,5 \pm 1,6$ & $36,7 \pm 1,8$ & $29,6 \pm 1,5$ & $23,6 \pm 1,2$ & $34,9 \pm 1,7$ \\
\hline
\end{tabular}

* Note: Sample 3 - mass \%: $N(5,9 \pm 0,3) ; S(1,1 \pm 0,05)$; atomic \%: $N(2,1 \pm 0,1) ; S(0,7 \pm 0,03)$.

On the EDX spectra of all experimental samples, peaks of about $0.8 ; 6,3$ and $6,8 \mathrm{keV}$ are associated with the absorption of kinetic energy of electrons by the Fe atom [27, 28]. The spectra of $\mathrm{NP} \mathrm{Fe}_{3} \mathrm{O}_{4}$ covered with egg white, linoleic acid, oil and starch contain two more peaks: about $0,27 \mathrm{keV}$ and $0,47 \mathrm{keV}$. These absorption bands belong to the $\mathrm{C}$ and $\mathrm{O}$ atoms $[27,28,34,35]$. Moreover, the peak at $0,47 \mathrm{keV}$, characteristic of the $\mathrm{O}$ atom, is also present in the spectrum of pure FAM; and the peaks of about 0,3 and 1,2 keV are associated with the absorption of kinetic energy by the electrons of the $\mathrm{N}$ and $\mathrm{S}$ atoms, respectively [27, 28, 34]. $\mathrm{Fe}, \mathrm{O}$, and $\mathrm{C}$ ( $\mathrm{H}$ cannot be investigated) and $\mathrm{N}$ and $\mathrm{S}$ (for sample 3) are the main components in the system "protein (fat, polysaccharide) of magnetofood" (Table 3). 
Thus, systems with $\mathrm{NPFe}_{3} \mathrm{O}_{4}$ have a chemical composition: sample 1 (FAM) - Fe 75,5\%; $\mathrm{O} 24,5 \%$; sample 2 ( $\mathrm{NPFe}_{3} \mathrm{O}_{4}$ covered with starch) - Fe 41,7\%; O 35,7\%; C 22,6\%; sample $3\left(\mathrm{NPFe}_{3} \mathrm{O}_{4}\right.$ covered egg white) - Fe 44,7\%; O 26, 9\%; C 21.4\%; N 5,9\%; S 1,1\%; sample 4 $\left(\mathrm{NPFe}_{3} \mathrm{O}_{4}\right.$ covered with rich linoleic acid) - Fe 45,6\%; O 34, 7\%; C 19,7\%; sample 5 $\left(\mathrm{NPFe}_{3} \mathrm{O}_{4}\right.$ coated with sunflower oil) - Fe 39,7\%; O 36,7\%; C 23,6\%.

So, in the experimental samples (2-5) a new chemical element (C) appears, and in the experimental sample 2 two more elements $(\mathrm{N}$ and $\mathrm{S}$ ), which are absent in pure FAM (sample 1). The result indicates that FAM nanoparticles were successfully obtained (sample 1) and the main substances of food systems: proteins, fats, polysaccharides (samples 2-5) chemosorbated on FAM particles.

\section{Determination of FAM bound moisture forms}

Depending on the heterogeneity of multicomponent systems, FAM can behave as a functional additive with a high hydration capacity with a wide range of actions in food production technologies, especially during the formation of various colloidal systems. Table 4 shows the coefficients of water absorption of FAM in media traditionally used in food technologies [45].

Coefficient of water absorption of FAM in various environments

Table 4

\begin{tabular}{|l|c|c|}
\hline \multirow{2}{*}{ Polar environment } & The coefficients of water absorption of FAM, \\
& \multicolumn{2}{|c|}{$\begin{array}{c}\mathbf{t}=\mathbf{2 0} \pm \mathbf{2}^{\circ} \mathbf{C} \\
\text { rel.un. }\end{array}$} \\
\cline { 2 - 3 } & $12,4 \pm 0,4$ & $12,8 \pm 0,4$ \\
\hline Sodium bicarbonate, $\mathrm{pH}=6,0$ & $12,8 \pm 0,4$ & $13,0 \pm 0,4$ \\
\hline Ethanoic acid solution, $\mathrm{pH}=4,5$ & $13,1 \pm 0,5$ & $13,4 \pm 0,5$ \\
\hline Sodium chloride solution, $0,5 \%$ & $13,4 \pm 0,5$ & $13,5 \pm 0,5$ \\
\hline Sodium chloride solution, $1,7 \%$ & $13,6 \pm 0,5$ & $13,7 \pm 0,5$ \\
\hline Solution of sucrose, $1,1 \%$ & $13,8 \pm 0,6$ & $14,0 \pm 0,6$ \\
\hline Solution of sucrose, $5,0 \%$ & $12,6 \pm 0,4$ & $12,9 \pm 0,4$ \\
\hline Milk & & \\
\hline
\end{tabular}

Increase in the temperature of the environment to $(50 \pm 2){ }^{\circ} \mathrm{C}$ (Table4) promotes hydration ability of FAM, which are caused, firstly, nano size particles $\mathrm{Fe}_{3} \mathrm{O}_{4}$ with a developed active surface area and a significant interaction of FAM particles with the aqueous phase [30, 33]; second, the presence of polarized sections, and structure-forming cations of iron on the surface, exhibit pronounced hydrophilic properties and childist to education aquacomplex $[31,32,37]$.

The clusterofilnosty NP "Magnetofood" (NPM) [30] and the presence of a defective near-surface layer [33, 35, 39] significantly affect the intensity of hydration - (degree of swelling, $\mathrm{K}_{\mathrm{sw}}$ ) and water absorptive capacity (WAC) of the food additive (Figure 6). 


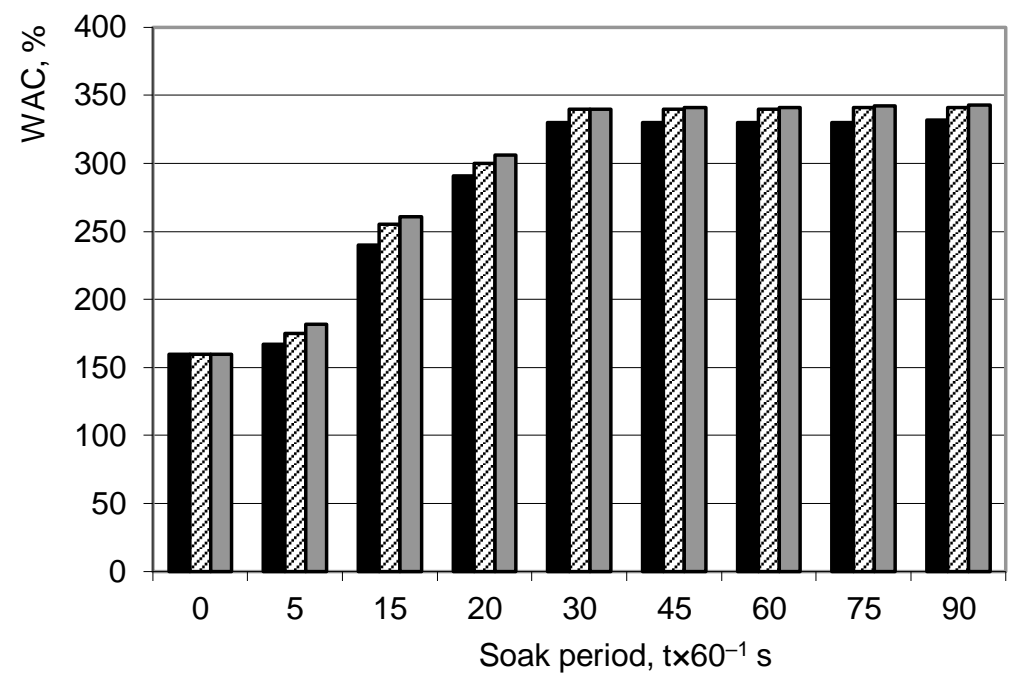

$a$

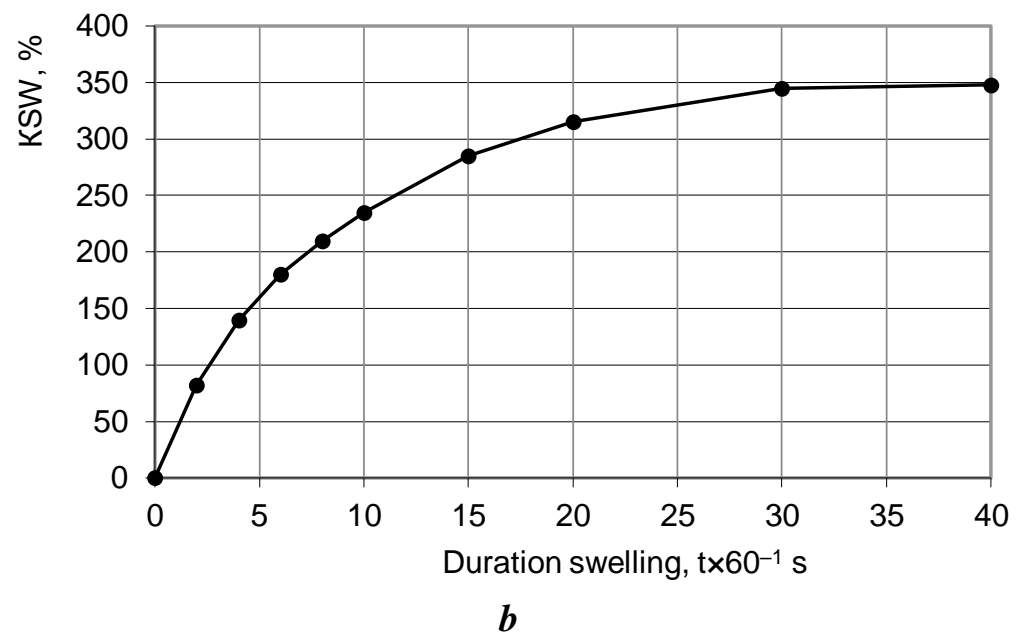

Figure 6. Intensity of FAM hydration:

a - WAC of "magnetofood+water" systems in the ratio of FAM: $\mathrm{H}_{2} \mathrm{O}$

$\square_{-1: 3 ;} \square_{-1: 5 ;} \square_{-1: 10 ;}$

b - swelling kinetics.

The weight of all systems "magnetofood+water" (Figure 6, a) is maximized by 2,0-2,2 times in $30 \times 60 \mathrm{~s}$. Thus, the greatest WAC is observed for these systems with a ratio of 1:5 and $1: 10$, and the minimum is $1: 3$. Region at $\tau<10 \times 60^{-1} \mathrm{~s}$ (Figure $6, \mathrm{~b}$ ) is characterized by high speed of swelling due to the filling of microdefects of the surface layer additives and water adsorption on the developed surface of NPM water molecules with their electrostatic forces as individual molecules or in the form of a film of a thickness of several molecules. Next, an aquacomplex is formed, since the following aquashares (polimolecular adsorption layers) appear on top of the formed aquaplive (monomolecular adsorption layer), which are attracted 
by molecular forces (including hydrogen bonds) [30, 32]. After $(25 \pm 5) \times 60 \mathrm{~s}$ the swelling process ends and reaches a maximum value of $\mathrm{K}_{\mathrm{sw}}=340-350 \%$.

Based on the analysis of the forms of water bond in FAM after swelling (indicator and thermogravimetric methods) the amount of bound water was determined: physical-chemical $68,9-69,4 \%$, physical-mechanical $21,5-22,3 \%$ and free $8,8-9,1 \%$ (Figure 7). This fact confirms the bound water capacity of FAM.

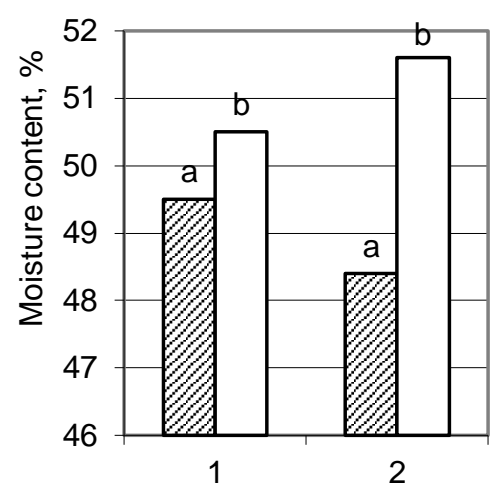

Figure 7. Distribution of water on the forms in the FAM after swelling, the specific methods:

1 - differential thermal analysis; 2 -indicator;

a - free, osmotic and physical-mechanical moisture;

$b$ - the amount of bound moisture

The ability of FAM to bound and retain water confirmed experimentally in model systems "rye-wheat flour (RWF)+magnetofood" and "starch+magnetofood" increase (compared to control): swelling $\left(S_{w}\right)$ of 1,15-1,2 times for starch and 1,1-1,3 times for flour and the water-retaining capacity (WRC) - 1,15-1,3 times for starch and-1,15-1,27 times for flour (Figure 8).
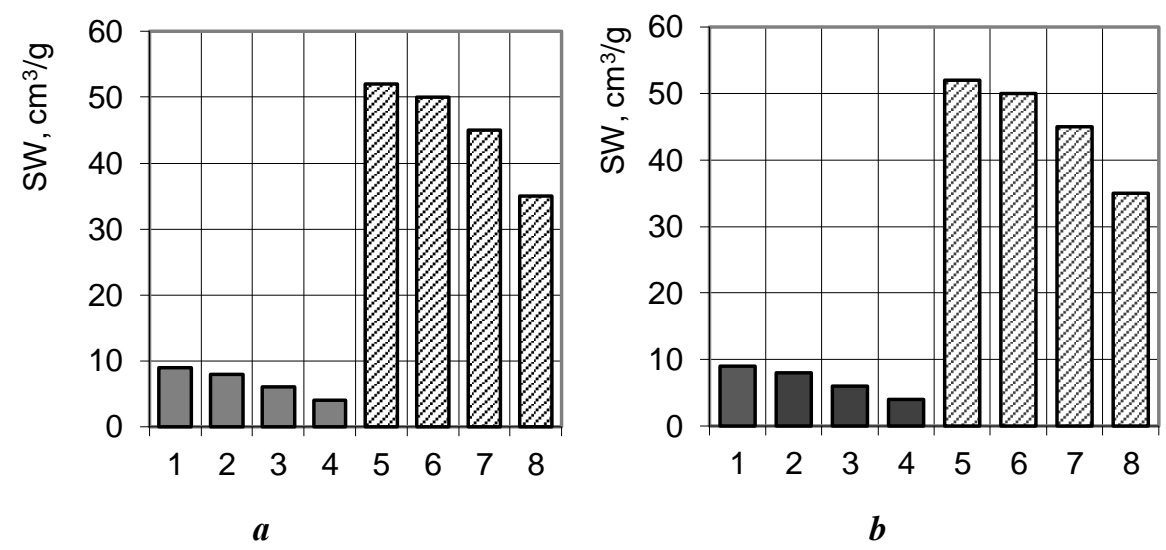

Figure 8. Swelling $(S w)$ (a) and WRC (b) systems "RWF+magnetofood" and "starch+magnetofood" with different amounts of FAM, mas.\%:

1,5 - RWF, starch $0,2 \% ; 2,6$ - RWF, starch $0,15 \%$;

3, 7 - RWF, starch 0, 1\%; 4, 8 - RWF, starch 0\% 
This is due to the ability NPM branching of the polymer chain of the macromolecules due to the "cavitativ", "clathrativ" and the side chains, extending the main chain of macromolecules of proteins and polysaccharides [30-32].

Also, the nanoparticles form a hydrophilic additive of solvatation with proteincarbohydrate complexes food systems, increasing haratio the ability of the feed components, in particular proteins and polysaccharides [30-32].

Under the influence of the applied shear stress, the formed aggregates are gradually destroyed, and in samples with FAM more slowly. This explains the high pseudoplasticity of water suspensions of experimental starch and flour samples. As a result, their viscosity decreases (Figure 9).

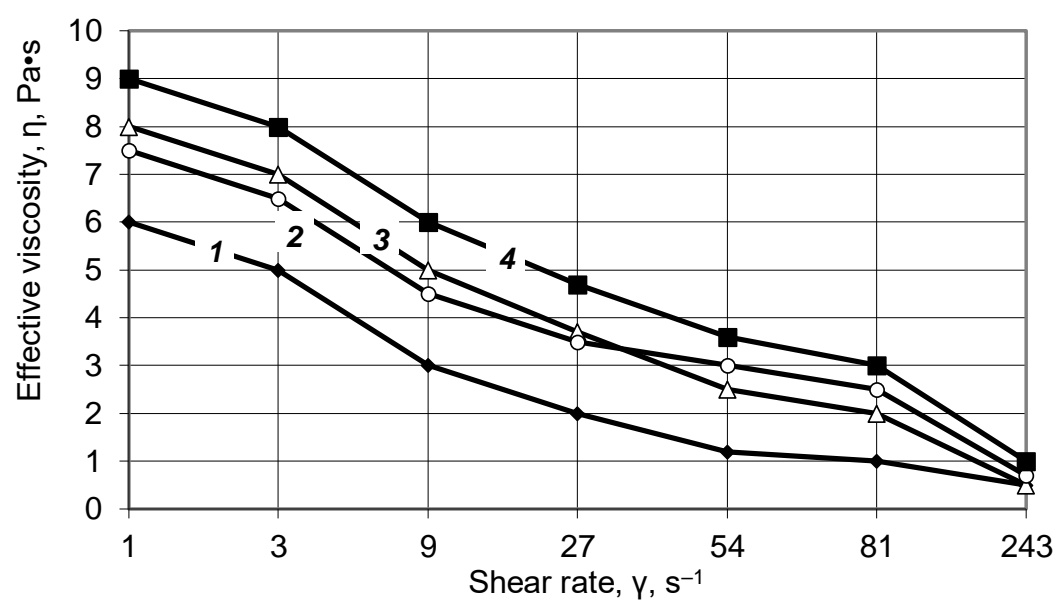

$a$

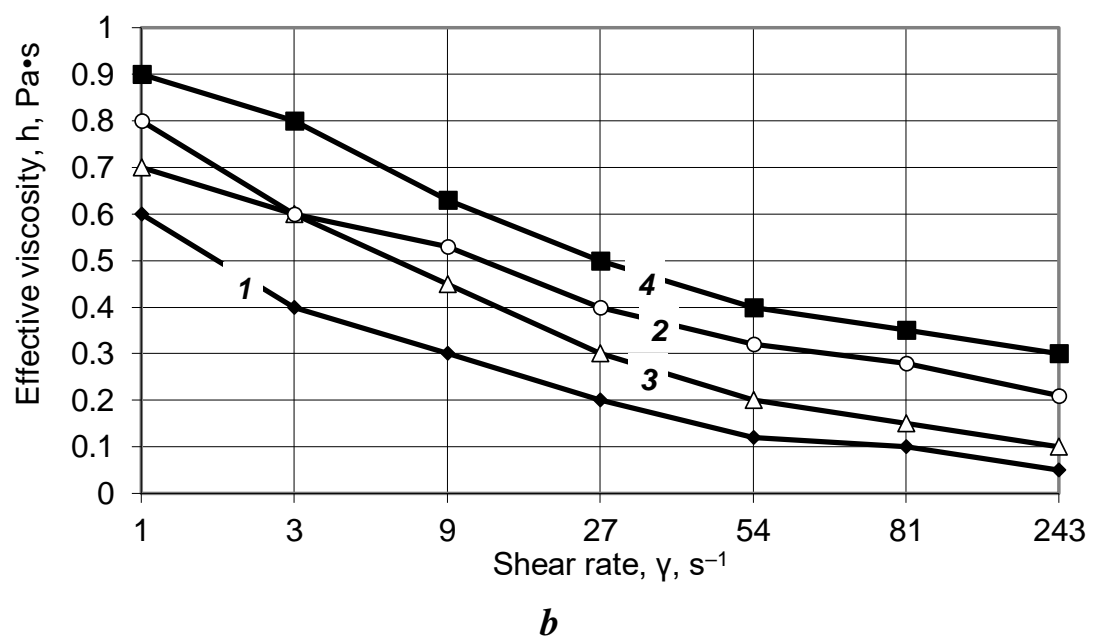

Figure 9. Effective viscosity of $13 \%$ of water suspensions at different temperatures and mass fraction of FAM, mas. \% : a - "starch (St)+magnetofood";

b - "RWF+magnetofood" $\left(1-\right.$ control and $2-0,15 \%$ FAM at $23{ }^{\circ} \mathrm{C}$; 3 - control and $4-0,15 \%$ FAM at $40{ }^{\circ} \mathrm{C}$ ) 
The use of FAM increases the viscosity of aqueous suspensions of starch and flour at both temperatures (compared to the control) by an average of $27-31 \%$ for starch and 20-24 $\%$ for flour at $21-25^{\circ} \mathrm{C}$ and $15,0-17 \%$ for starch and $9-11 \%$ for flour at $38-42{ }^{\circ} \mathrm{C}$. That is, the process of destruction of the internal structures of the dispersed system is slowed down when adding FAM to the system (due to the structure-forming and stability-forming ability of this additive) [30-32]. Moreover, the introduction of FAM into the system accelerates and strengthens the processes of hydration and dissolution of starch and flour [30, 37, 38].

Increase in the viscosity of $13 \%$ of water suspensions of starch and flour during proofing (shear rate $\gamma=9 \mathrm{~s}^{-1}$ ) $-30 \times 60^{-1} \mathrm{~s}$ (Figure 10) by 1,15-1,35 times at temperature of $21-25^{\circ} \mathrm{C}$ and 1,13-1,26 times at a temperature of 38-42 ${ }^{\circ} \mathrm{C}$ for starch and 1,1-1,27 times at a temperature of $21-25^{\circ} \mathrm{C}$ and $1,1-1,22$ times at a temperature of $38-42{ }^{\circ} \mathrm{C}$ for flour (compared to the control) is associated with the continuation of the processes of hydration and dissolution (due to the clusterofilnosti and amphifilnosti FAM) [30, 33].

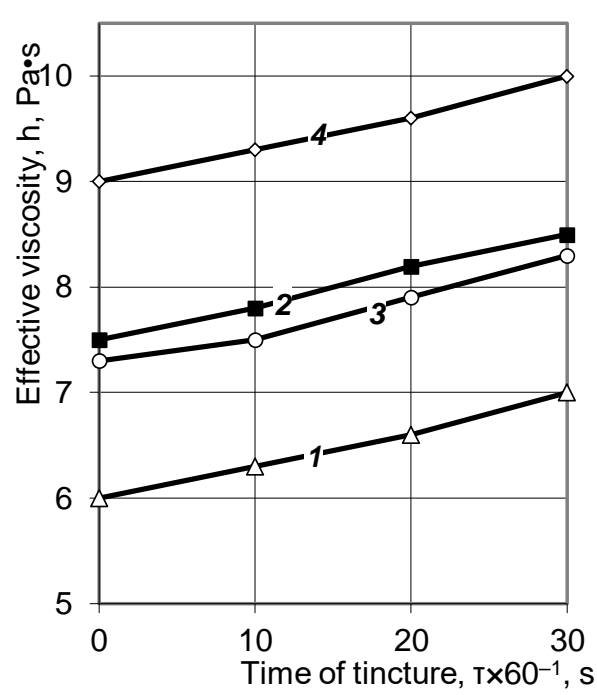

$a$

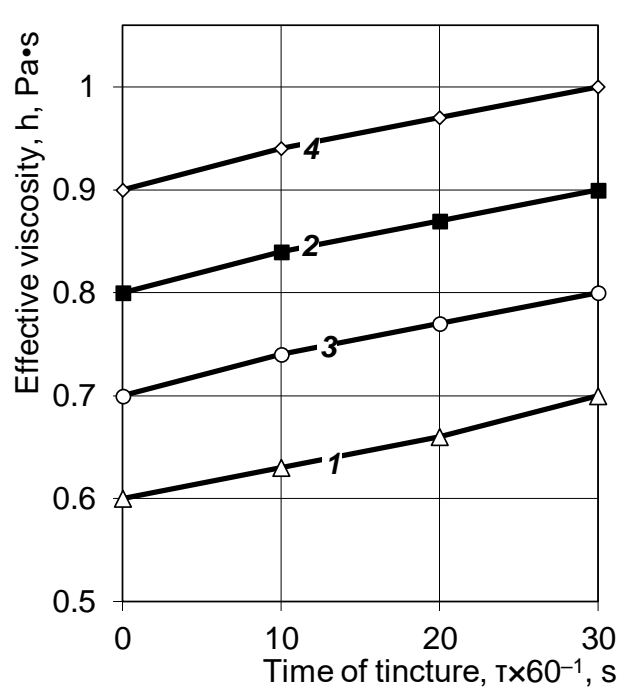

$b$

Figure 10. Dependence of the effective viscosity of $13 \%$ water suspensions on the time of tincture at different amounts of FAM, mas.\%: a - "starch (St)+magnetofood"; b - "RWF+ magnetofood" ( 1 - control and $2-0,15 \%$ FAM at $23{ }^{\circ} \mathrm{C}$; 3 - control and $4-0,15 \%$ FAM at $40{ }^{\circ} \mathrm{C}$ )

Adding a food additive based on double oxide of two- and trivalent iron "Magnetofood" (FAM) to the system accelerates and strengthens the processes of hydration and dissolution of starch and flour. The thickening properties of the food additive and its ability to bind and retain water have been experimentally confirmed. These properties are important in hal- and foam-like, emulsified and emulsified-suspension systems. 


\section{Conclusions}

Proved the mechanism of water retention nanoparticles of food additives, based of double oxide of two- and trivalent iron "Magnetofood" $\left(\mathrm{Fe}_{3} \mathrm{O}_{4}\right)$ due to clusterophilicity and amphiphilicity food supplements and the ability of $\mathrm{NPFe}_{3} \mathrm{O}_{4}$ polarization, electrostatic coordination, formation of aqua associates. The introduction of a food additive based on double oxide of two- and trivalent iron "Magnetofood" into the poliphase system increases the water-retaining capacity of its components (in particular, proteins, polysaccharides), which contributes to improving the quality indicators and shelf life of finished products in comparison with the control.

The conducted research shows the high hydration capacity of a food additive based on double oxide of two- and trivalent iron "Magnetofood" (FAM), which in food production technologies can improve the functional and technological properties of heterogeneous dispersed systems and improve the timing of preserving the freshness of finished products.

\section{References}

1. Trokhymenko V., Kalchuk L., Didukh M., Kovalchuk T., Zakharin V. (2018), Vykorystannia kharchovykh dobavok u kovbasnomu vyrobnytstvi ta yikh vplyv na orhanizm liudyny, Visnyk Sumskoho natsionalnoho ahrarnoho universytetu, Seriia «Tvarynnytstvo», 2(34), pp.233-237.

2. Maforimbo E., Skurray G., Nguyen M. (2007), Evaluation of 1-ascorbic acid oxidation on SH concentration in soy-wheat composite dough during resting period, Food Sci. and Technol., 40(2), pp. 338-343.

3. Rosell C., Aja S., Bean S., Lookhart G. (2003), Wheat flour proteins as affected by transglutaminase and glucose oxidase, Cereal Chem., 80(1), pp. 52-55.

4. Chugunova O., Pastushkova E. (2015). Modelirovaniye organolepticheskikh pokazateley khleba s rastitelnymi dobavkami. Vestnik YuUrG,. Seriya «Pishchevyye i biotekhnologii», 3(4), pp. 80-87.

5. Tamazova S., Lisovoi V., Pershakova T., Kazimirova M. (2016), Pishchevye dobavki na osnove rastitelnogo syria, primeniaemye $\mathrm{v}$ proizvodstve khlebobulochnykh i muchnikh konditerskikh izdelii, Politematicheskii setevoi elektronnyi nauchnyi zhurnal KubGAU, 122(8), pp. 1-8.

6. Rosliakov Iu.F., Vershinina O.L., Gonchar V.V. (2016), Nauchnye razrabotki dlia khlebopekarnoi i konditerskoi otraslei, Tekhnologii pishchevoi i pererabatyvaiushchei promyshlennosti, APK-produkty zdorovogo pitaniia, 6, pp. 1-6.

7. Rosliakov Ju., Vershinina O., Gonchar V. (2010), Perspektivnye issledovaniia tekhnologii khlebobulochnykh izdelii funktsionalnogo naznacheniia, Izvestiia vuzov, Pishchevaia tekhnologiia, 1, pp.123-125.

8. Gorshunova K., Semenova P., Bessonov V. (2012), Vzaimodeistvie gidrokolloidov i vodorastvorimykh vitaminov pri konstruirovanii obogashchennykh pishchevykh produktov, Pishchevaia promyshlennost, 11, pp. 46-49.

9. Filips G. O, Viliams P. A. (2006), Spravochnik po gidrokolloidam, Per. s angl. pod red. Kochetkovoi A. A. i Sarafanovoi L. A., GIORD, Sankt-Peterburg.

10. (2013), Tsitrusovye volokna Herbacel AQ Plus - tip N: spetsifikatsii dlia pishchevykh dobavok i retseptury, Available at: http://specin.ru. 
11. Domoroshchenkova M., Demianenko T., Kamysheva I. (2007), Issledovanie funktsionalno-tekhnologicheskikh svoistv izoliatov soevykh belkov, Maslozhirovaia promyshlennost, 4, pp. 24-28.

12. Renziaeva T., Pozniakovskii V. (2009), Vodouderzhivaiushchaia sposobnost syria i pishchevykh dobavok $\mathrm{v}$ proizvodstve muchnykh konditerskikh izdelii, Khranenie $i$ pererabotka selkhozsyria, 8, pp. 35-38.

13. Renziaeva T., Tuboltseva A., Ponkratova E., Lugovaia A., Kazantseva, A. (2014), Funktsionalno-tekhnologicheskie svoistva poroshkoobraznogo syria i pishchevykh dobavok $\mathrm{v}$ proizvodstve konditerskikh izdelii, Tekhnika $i$ tekhnologiia pishchevykh proizvodstv, 4, pp. 43-49.

14. Anup S., Atanu H., Shrikant C. (2012), Comprehensive Reviews in Food Science and Food Safety, Institute of Food Technologists, 11, pp. 518-528.

15. Bae S., Cho M., Jeong J. (2017), Effects of Various Calcium Powders as Replacers for Synthetic Phosphate on the Quality Properties of Ground Pork Meat Products, Korean J. Food Sci Anim Resour, 37(3), pp. 456-463.

16. Martins Z., Pinho O., Ferreira, I. (2017). Food industry by-products used as functional ingredients of bakery products, Trends in Food Science \& Technology, 67, pp. 106-128.

17. Lai W., Khong N., Lim S., Hee Y., Sim B., Lau K., Lai O. (2017), A review: Modified agricultural by-products for the development and fortification of food products and nutraceuticals, Trends in Food Science \& Technology, 59, pp. 148.

18. Bharath K., Prabhasankar P. (2014), Low glycemic index ingredients and modified starches in wheat based food processing: A review, Trends in Food Science \& Technology, 35(1), pp. 32-41.

19. Ngemakwe P., Le Roes-Hill M., Jideani V. (2014), Advances in gluten-free bread technology, Food Science and Technology International, 21(4), pp. 256-276.

20. Bird L., Pilkington C., Saputra A., Serventi L. (2017), Products of chickpea processing as texture improvers in gluten-free bread, Food Science and Technology International, 23(8), pp. 690-698.

21. García-Segovia P., Pagán-Moreno M., Lara I., Martínez-Monzó J. (2017), Effect of microalgae incorporation on physicochemical and textural properties in wheat bread formulation, Food Science and Technology International, 23(5), pp. 437-447.

22. Boubaker M., Omri A., Blecker C., Bouzouita N. (2016), Fibre concentrate from artichoke (Cynara scolymus L.) stem by-products: Characterization and application as a bakery product ingredient, Food Science and Technology International, 22(8), pp. 759-768.

23. Ramachandraiah K., Choi M.-J., Hong G.-P. (2018), Micro- and nanoscaled materials for strategy-based applications in innovative livestock products: A review, Trends in Food Science \& Technology, 71, pp. 25-35.

24. Hansen S., Heggelund L., Besora P., Mackevica A., Boldrin A., Baun A. (2016), Nanoproducts - what is actually available to European consumers?, Environmental Science: Nano, 1, pp. 1-8.

25. Thiruvengadam M., Rajakumar G., Chung M. (2018), Nanotechnology: current uses and future applications in the food industry, 3 Biotech, 8(1), pp. 74-83.

26. Drmota A., Kosak A., Znidarsik A. (2008), A mechanism for the adsorption of carboxylic acids onto the surface of magnetic nanoparticles, Materials and technology, 42, pp. 79 83.

27. Mahdavi M., Ahmad M. B., Haron M., Namvar F., Nadi B., Ab Rahman M., Amin J. (2013), Synthesis, Surface Modification and Characterisation of Biocompatible Magnetic Iron Oxide Nanoparticles for Biomedical Applications, Molecules, 18, pp. 7533-7548. 
28. Zhang L., He R., Gu H.-C. (2006), Oleic acid coating on the monodisperse magnetite nanoparticles, Applied Surface Science, APSUSC-14301, 7, pp. 1-7.

29. Chernyshova I., Ponnurangam S., Somasundaran P. (2011), Adsorption of Fatty Acids on Iron (Hydr)oxides from Aqueous Solutions, Langmuir, 27(16), pp. 10007-10018.

30. Tsykhanovska I., Evlash V., Alexandrov A., Lazareva T., Svidlo K., Gontar T., Yurchenko L., Pavlotska L. (2018), Substantiation of the mechanism of interaction between biopolymers of rye-and-wheat flour and the nanoparticles of the «Magnetofood» food additive in order to improve moisture-retaining capacity of Dough, EasternEuropean Journal of Enterprise Technologies, 2/11(92), pp. 70-80.

31. Tsykhanovska I., Evlash V., Alexandrov A., Lazareva T., Bryzytska O. (2018), Substantiation of the interaction between the lipo- and glucoproteids of rye-wheat flour and nanoparticles of the food additive «Magnetofood», Eastern-European Journal of Enterprise Technologies, 4/11(94), pp. 61-68.

32. Tsykhanovska I., Evlash V., Alexandrov A., Lazareva T., Yevlash T. (2018), Substantiation of the mechanism of interaction of between the carbohydrates of ryewheat flour and nanoparticles of the polyfunctional food additive «Magnetofood», Eastern-European Journal of Enterprise Technologies, 3/11(93), pp. 59-68.

33. Levitin E. Ia., Vedernikova I. A., Tsikhanovskaia I. V. (2007), Issledovanie elektropoverkhnostnykh svoistv magnetitovykh dispersnykh sistem na vodnoi osnove, Eastern-European Journal of Enterprise Technologies, 3/4 (27), pp. 16-18.

34. Tsykhanovska I., Evlash V., Alexandrov A., Gontar T. (2018), Mechanism of fat-binding and fat-contenting of the nanoparticles of a food supplement on the basis of double oxide of two- and trivalent iron, Ukrainian Food Journal, 7(4), pp. 702-715.

35. Tsykhanovska I., Evlash V., Alexandrov A., Gontar T., Shmatkov D. (2019), The study of the interaction mechanism of linoleic acid and 1-linoleyl-2-oleoyl-3-linolenoylglycerol with $\mathrm{Fe}_{3} \mathrm{O}_{4}$ nanoparticles, Chemistry \& chemical technology Chemistry, 13(3), pp. 303-316.

36. Iliukha N., Barsova Z., Kovalenko V., Tsikhanovskaia I. (2010), Tekhnologiia proizvodstva i pokazateli kachestva pishchevoi dobavki na osnove magnetita, EasternEuropean Journal of Enterprise Technologies, 6/10(48), pp. 32-35.

37. Tsykhanovska I., Evlash V., Alexandrov A., Lazareva T., Yevlash T. (2018), Investigation of the water-retaining capacity of the carbohydrate complex of rye-wheat dough with addition of polyfunctional food supplement «Magnetofood», Eureka: Life Sciences, 3/15(3), pp. 56-64.

38. Tsykhanovska I., Yevlash V., Lazarieva T., Shynhisov A. (2019), Doslidzhennia strukturno-mekhanichnykh pokaznykiv ta pinoutvorennia zefirnykh mas z riznymy strukturoutvoriuvachamy pry vvedenni v retsepturu kharchovoi dobavky «Mahnetofud», Pratsi TDAU, Tekhnichni nauky, 2(19), pp. 168-189.

39. Aleksandrov O.V., Tsykhanovska I.V., Barsova Z.V., Dudenko N.V., Pavlotska L.F., Skurikhina L.A. (2015), Kolektyvna monohrafiia, Povnotsenne kharchuvannia: innovatsiini aspekty tekhnolohii, enerhoefektyvnoho vyrobnytstva, zberihannia ta marketynhu, Oderzhannia ta doslidzhennia vlastyvostei biolohichno-aktyvnykh dobavok na osnovi lipido-mahnetytovykh suspenzii, KhDUKhT, Kharkiv, pp. 138-167.

40. Tsykhanovska I., Aleksandrov O., Lazarieva T., Hontar T., Pavlotska L. (2016), Kolektyvna monohrafiia, Povnotsenne kharchuvannia: innovatsiini aspekty tekhnolohii, enerhoefektyvnoho vyrobnytstva, zberihannia ta marketynhu, Vykorystannia zhyromahnetytovoi suspenzii dlia pidvyshchennia kharchovoi tsinnosti tsukerok «Sukhofrukty $v$ shokoladi», zbahachenykh zalizovmisnoiu kharchovoiu dobavkoiu, KhDUKhT, Kharkiv, pp. 143-170. 
41. Tarasiuk N., Barsova Z., Tsykhanovska I. (2012), Tekhnolohiia otrymannia oliinomahnetytovыkh suspenzii, Khimichni Karazinski chytannia - 2012 (KhKCh12): tezy IKh Vseukr. nauk. konf., 23-26 kvitnia 2012 roku, Kharkivskyi natsionalnyi un-t im. V. N. Karazina. pp. 326-327.

42. Tsykhanovska I., Alexandrov A., Gontar T., Kokodiy N., Dotsenko N. (2016), Stability and morphological characteristics of lipid-magnetite suspensions, Eureka: Life Sciences, $3(3)$, pp. $14-25$.

43. Iurchak V., Berzina N., Shmarovoz V., Prishchepa M. (1989), Opredelenie sviazannoi vody indikatornym metodom $\mathrm{v}$ khlebopekarnom proizvodstve, Izvestiia vuzov, Pishchevaia tekhnologiia, 4, pp. 78-80.

44. Nilova L., Kalinina I., Naumenko N. (2013), Metod differentsialno-termicheskogo analiza $\mathrm{v}$ otsenke kachestva pishchevykh produktov, Vestnik IuUrGU, Pishchevye $i$ biotekhnologii, 1(1), pp. 43-49.

45. Krainiuk L., Savgira Iu., Pozdniakova E., Iancheva M. (2000), K voprosu o sovershenstvovanii metodiki opredeleniia vodosviazyvaiushchei sposobnosti miasa i miasoproduktov, Progresivni tekhnologii ta udoskonalennia protsesiv kharchovikh virobnitstv: zb. nauk. prats, 1, pp. 119-123.

46. Svidlo K., Peresichnyi M. (2011), Technology of functional public catering foods with dietary additives, Proceedings of 11th International Congress on Engineering and Food «Food Process in Changing World», 22-26 May 2011, National Technical University of Athens, School of Chemical Engineering, pp. 2035-2037.

47. Diakov A., Torianik A., Svidlo K., Lipovoi D. (2013), Issledovanie vlagosoderzhaniia shrota i kletchatki ovsa i proektirovanie na ikh osnove tekhnologii smuzi gerodieticheskogo naznacheniia, Protsessy $i$ apparaty pishchevykh proizvodstv, SanktPeterburg: SPBGUNiPT, 1, pp. 10.

48. Rikhter M., Augustat Z., Shirbaum F. (1975), Izbrannye metody issledovaniia krakhmala, Pishchevaia promyshlennost, Moscow.

49. Renziaeva T., Pozniakovskii V. (2009), Vodouderzhivaiushchaia sposobnost syria i pishchevykh dobavok $\mathrm{v}$ proizvodstve muchnykh konditerskikh izdelii, Khranenie $i$ pererabotka selkhozsyria, 8, pp. 35-42.

50. Posudin Y.I., Peiris K.S., Kays S.J. (2015), Non-destructive detection of food adulteration to guarantee human health and safety, Ukrainian Food Journal, 4(2), pp. 207-260. 